\title{
CURRENT OVERVIEW OF COVID-19 VACCINATION PROCESS IN SERBIA
}

\author{
Aleksandra Catić Djordjević ${ }^{1}$, Nikola Stefanović ${ }^{1}$, Ana Spasić ${ }^{1}$, Ivana Damnjanović ${ }^{1}$, \\ Radmila Veličković Radovanović1,2, Boris Djindjić1,3, Dragana Pavlović ${ }^{1}$
}

It has been more than a year since the beginning of the coronavirus disease 2019 (COVID-19) pandemic caused by severe acute respiratory syndrome coronavirus 2 (SARS-CoV2). As a result of collaborations of worldwide researchers, four COVID-19 vaccines of different manufacturers and types are available in Serbia since December 2020, and citizens can choose one of them. Mild to moderate adverse effects are expected and usually resolve within one day after vaccination.

This study aimed to make a current overview of the vaccination process in Serbia as a cross-section of attitudes and adverse effects related to the COVID-19 vaccines during the period of mass vaccination.

The data were collected via the online survey platform. The participants were invited to voluntarily complete an online questionnaire in their native language from the beginning of March to April 12, 2021.

The conducted research included 573 respondents who filled out the questionnaire: $174(30.37 \%)$ men and $399(69.63 \%)$ women, with an average age of $43.55 \pm 13.17$ years. The largest number of respondents received Pfizer/BioNTech $(40.14 \%)$ or Sinopharm vaccine (42.93\%). Pfizer/BioNTech vaccine prevalence was higher among male respondents, healthcare professionals, and the younger population. The most common local adverse effect included pain or tenderness at the injection site. Fever, muscle/joint pain, and tiredness were reported as the most common systemic adverse effects, especially after the second dose of vaccines.

The vaccination process in Serbia started quickly and is persisting with high intensity. A widespread vaccination process can lead to pandemic control and a reduction in SARS-CoV-2induced death.

Acta Medica Medianae 2021;60(3):20-29.

Key words: pandemic, COVID-19, SARS-CoV-2, vaccination

${ }^{1}$ University of Niš, Faculty of Medicine, Niš, Serbia

2University Clinical Center Niš, Clinic of Nephrology, Niš, Serbia

${ }^{3}$ University Clinical Center Niš, Clinic of Cardiovascular

Diseases, Niš, Serbia

Contact: Aleksandra Catić Đorđević

81 Dr Zoran Djindjić Blvd., 18000 Niš, Serbia

E-mail: aleksandra.catic@medfak.ni.ac.rs

\section{Introduction}

Coronavirus disease 2019 (COVID-19) caused by severe acute respiratory syndrome coronavirus 2 (SARS-CoV-2) was first reported in December 2019 in Wuhan, China and has since spread globally, causing a pandemic (1). Clinical experience indicates that COVID 19 is very unpredictable, ranging from asymptomatic cases, through mild symptoms to severe pneumonia, multi-organ failure, and death More than 135 million cases have been registered all over the world, resulting in more than 2.92 million deaths (2). Institutions and companies worldwide have teamed up to develop treatments and vaccines against COVID-19.

Four COVID-19 vaccines of different manufacturers and types are available in Serbia since December 2020, and citizens can choose one of them. All vaccines are administered in 2 doses separated by 21 days, except AstraZeneca whose second dose is administered after three months. Until April $12,2021,2,882,854$ doses of the COVID-19 vaccine were administered in Serbia, $25 \%$ of the total population received at least one dose, and $17 \%$ were fully vaccinated against COVID-19 (3).

The Pfizer-BioNTech COVID-19 vaccine contains mRNA for the synthesis of the spike glycoprotein SARS-CoV-2, which is recognized as a key virus antigen (4). The immune system recognizes this spike glycoprotein as a foreign molecule and creates protective immunity. mRNA does not multiply in the cell and is very quickly broken down and removed (5). 
The vaccine developed by the Oxford University-AstraZeneca collaboration was made by inserting the SARS-CoV-2 spike glycoprotein gene into the chimpanzee adenovirus genome (6). The adenovirus serves as a vector (carrier). This altered form of adenovirus cannot multiply in human cells or cause disease, which makes it safe.

The Gamaleya National Center of Epidemiology and Microbiology in Moscow has developed the Sputnik $V$ vaccine which is a vector vaccine and contains human adenovirus as a carrier (7). Due to the fact that immune response also develops to parts of the vector, the adenovirus serotype differs in the first and second doses. The spike glycoprotein gene is the same in both types of adenovirus.

Sinopharm vaccine is a traditionally made vaccine inactivated by a chemical agent. Inactivated (dead) SARS-CoV-2 does not have the ability to reproduce but retains the ability to trigger an immune response (8).

The most common side effects of the vaccines include pain, swelling, and redness at the injection site, while headache, nausea, and fever usually occur as systemic reactions on the first or second day after vaccination. In rare cases, vaccines can cause a severe allergic reaction and therefore medical supervision is necessary immediately after administration (9).

The aim of this study was to make a crosssection of attitudes related to the COVID-19 vaccines during the period of mass vaccination of Serbian citizens. As a second goal, we analyzed reported adverse effects in relation to the first and second dose of the vaccines.

\section{Materials and methods}

This research was conducted to identify possible adverse effects after vaccines against COVID19 in adults in Serbia. The data collection was con- ducted via the online survey platform (google.doc) because of the restriction of movement and the need for social distance. The participants were invited to complete an online questionnaire in their native language during March and April 2021. The questionnaire was filled out voluntarily by 639 respondents. The questionnaire contained 19 required questions, mostly close-ended. The first part of the questionnaire included the socio-demographic characteristics of the respondents. The following questions were related to risk perception and preventive measures for COVID-19, knowledge, and information sources about vaccines. In addition, subjects were asked to describe the type, intensity, and duration of adverse effects after the first and second dose of the vaccine.

Descriptive statistics were calculated for the demographic characteristics of the participants in this study. A Chi-square test was used to examine the relationship between the demographic characteristics of the participants and chosen vaccines. A pvalue less than 0.05 was considered statistically significant. Statistical analysis was performed using SPSS Statistics 20.0.

\section{Results and discussion}

We analyzed the 639 responses completed by Serbian residents over 18 years of age. Sixty-six surveys were excluded from the research, 65 respondents did not receive a second dose of the vaccine, and 1 respondent received a vaccine that was not available in Serbia. Of the 573 volunteers participating in the study, 174 (30.37\%) were men and $399(69.63 \%)$ were women. The average age was $43.55 \pm 13.17$ years, where the youngest respondent was 19, and the oldest was 91 years old. The demographic characteristics of respondents are shown in Table 1.

Table 1. Demographic characteristics of respondents $(N=573)$

\begin{tabular}{||l|c||}
\hline \hline Sex (male) & $174(30.37 \%)$ \\
\hline Age (years) & $\begin{array}{c}43.55 \pm 13.17 \\
42(35-50)\end{array}$ \\
\hline Education level & $34(5.93 \%)$ \\
\hline Secondary: medical orientation & $96(16.75 \%)$ \\
\hline Bachelor or Master: medical orientation & $91(15.88 \%)$ \\
\hline $\begin{array}{l}\text { Doctoral studies or, specialization of healthcare } \\
\text { Professional: medical orientation }\end{array}$ & $63(11.00 \%)$ \\
\hline Secondary: non-medical orientation & $210(36.65 \%)$ \\
\hline Bachelor or Master: non-medical orientation & $79(13.79 \%)$ \\
\hline Doctoral studies: non-medical orientation &
\end{tabular}

Considering the education level of the respondents, 97 (16.93\%) were high-school graduates, 306 (53.4\%) were university graduates and 170 $(29.67 \%)$ had a doctoral degree (Ph.D.) or specia- lization (only applicable for MDs). Among them, 221 $(38.57 \%)$ were healthcare professionals, and 352 $(61.43 \%)$ were non-healthcare professionals (Graph 1). 


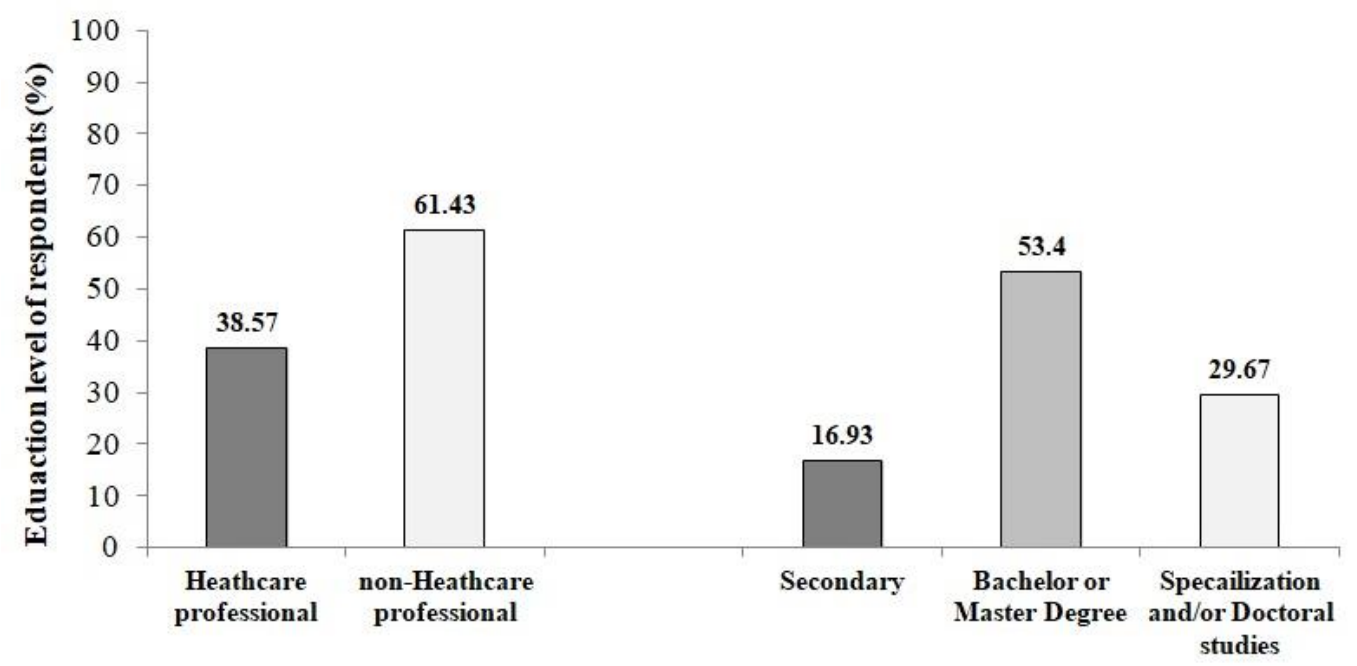

Graph 1. Education level of respondents

Of the total number of respondents, 488 $(85.17 \%)$ believed that SARS-CoV-2 infection was a global medical problem of the highest rank, while 75 $(13.09 \%)$ believed that SARS-CoV-2 infection was a global medical problem similar to seasonal flu. Only ten subjects $(1.74 \%)$ included in this study believed that SARS-CoV-2 infection was not a serious medical problem.

The risk of SARS-COV-2 infection varied depending on the respondents' profession (Graph 2). Very high risk (constant contact with infected people, like a doctor in COVID unit) was reported by $75(13.09 \%)$ respondents, high risk (constant contact with a large number of strangers, like vendor) in 123 (21.47) respondents, moderate risk (constant contact with a large number of the same people, like work in a factory) was reported by 96 (16.75\%) respondents, while 167 (29.14\%) had a low risk (constant contact with a small number of the same people, like office work), and very low risk (no contact with other people, like freelancer, work from home) was reported by 112 (19.55\%) respondents.

Risk of SARS-CoV2 infection - respondents (\%)

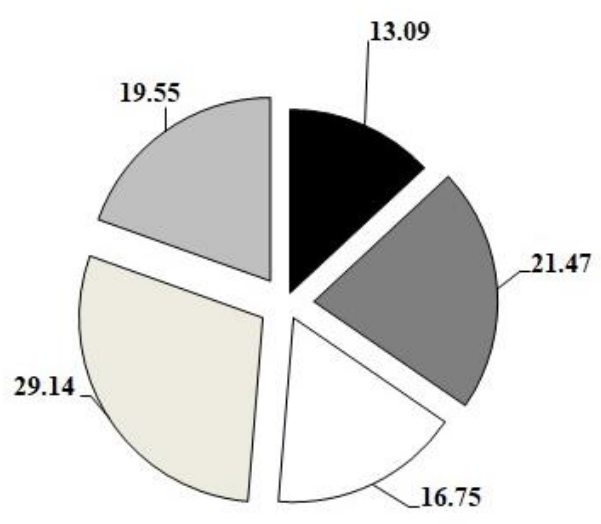

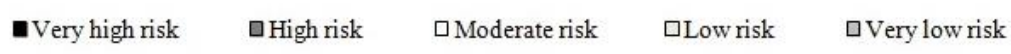

Graph 2. Risk of SARS-CoV-2 infection in relation to the respondents' profession 
Most of the respondents (77.49\%) were vaccinated to protect themselves and people in their environment (family, friends, and colleagues). In addition, $14.83 \%$ of respondents wanted to have the ability to travel and avoid restrictions in the country and abroad, and $7.68 \%$ of respondents stated all the offered answers as a reason for vaccination (Graph 3).

Graph 4 shows the prevalence of different types of vaccines among the respondents. A similar prevalence of Pfizer/BioNTech and Sinopharm vaccines was observed, which is in accordance with the availability of vaccines during the study period in Serbia. Serbia has focused its early vaccination efforts on priority groups like the elderly people with chronic disease, and front-line workers, like healthcare professionals.

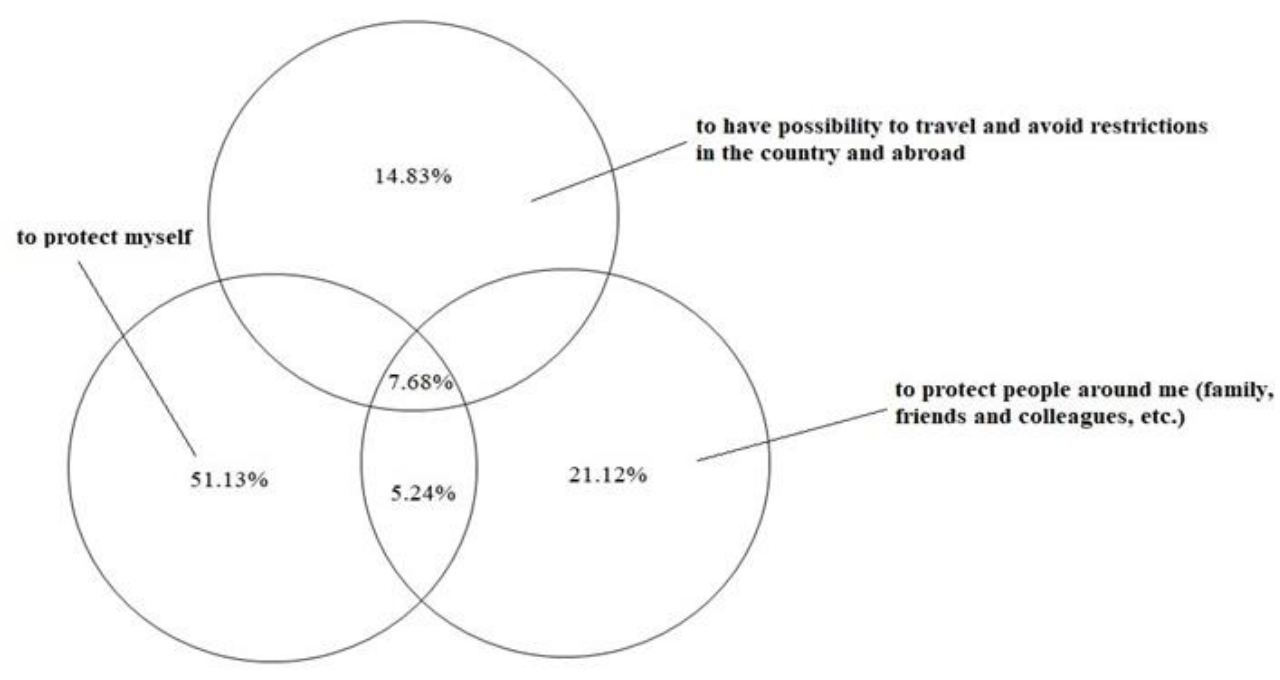

Graph 3. Reason for vaccination

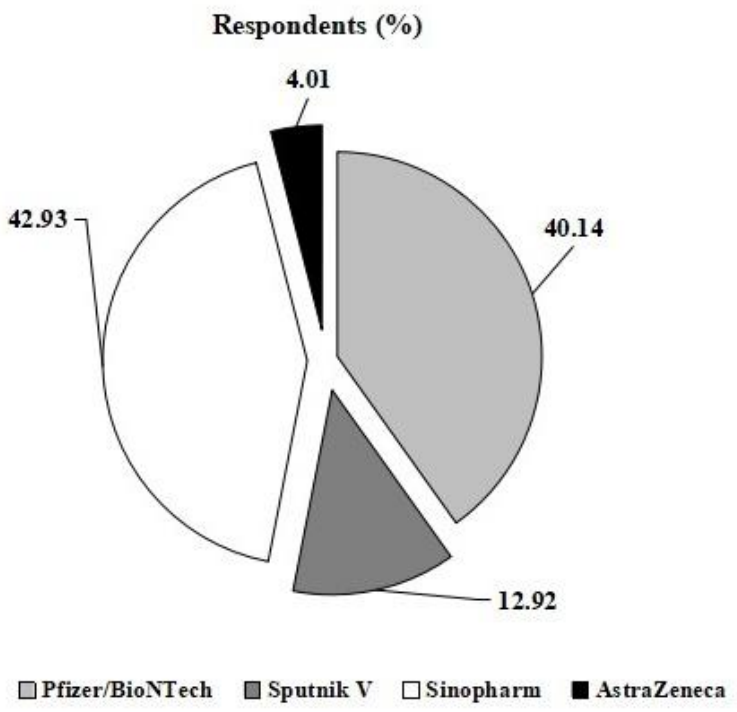

Graph 4. Prevalence of vaccines among the respondents 
The reason for the vaccine choice among the respondents is shown in Graph 5. The most common source of information about COVID-19 vaccines was scientific journals ( $n=226,39.44 \%)$. This was followed by media releases ( $n=59,10.3 \%$ ), while consultation with the general practitioner was the main source of information for 51 respondents $(8.9 \%)$. Availability of the vaccines at that moment was crucial for 213 (37.17\%) respondents. Due to reduced choice in the first month of mass vaccination, it is necessary to compare this percentage to a larger sample of respondents over a longer period of time.
Sallam et al. reported that the most common source of information about COVID-19 vaccines was reliance on medical doctors, scientists, and scientific journals (10). Earnshaw et al. confirmed that doctors were the most trusted source of information about COVID-19, which highlights the significance of their role (11). On the other hand, social media platforms as sources of information were associated with more doubts, misbeliefs, and spread of misinformation regarding the vaccines (12).

\section{Reason for the chosen vaccine - respondents (\%)}



Graph 5. Reason for the chosen vaccine

The prevalence of different types of vaccines in relation to gender, age, professional orientation, and level of education are shown in Graphs 6, 7, 8, 9 , respectively.

The prevalence of Pfizer/BioNTech vaccine was higher among male respondents compared to females (44.25\% vs. 38.35\%) while the prevalence of Sinopharm vaccine was higher in females $\left(\chi^{2}=\right.$ 17.993, $\mathrm{p}<0.001)$.

Elderly respondents ( $\geq 65$ years old) mostly received the Sinopharm vaccine while Pfizer/BioNTech was more prevalent in the younger population $\left(\chi^{2}=43.02, p<0.001\right)$. This is in line with existing government recommendations.

The prevalence of Pfizer/BioNTech vaccine was higher among healthcare professionals while the prevalence of Sinopharm vaccine was higher in nonHealthcare professionals $\left(\chi^{2}=33.71, p<0.001\right)$. There was no difference in the prevalence of vacci- nes in relation to the level of education $\left(\chi^{2}=7.148\right.$, $p=0.307)$.

Table 2 shows the reported adverse effects after vaccination. The most common local adverse effect included pain or tenderness at the injection site. Fever, muscle/joint pain, and tiredness were reported as the most common systemic adverse effects, especially after the second dose of vaccines. This is consistent with findings from other studies (5, $8,13,14)$.

The frequency and duration of adverse effects after the first and second doses of the vaccine are shown in Graphs 10 and 11, respectively.

Adverse effects, especially systemic were more common after the second dose $\left(\chi^{2}=15.688\right.$, $\mathrm{p}<0.001$ ) and usually lasted up to one day after vaccination. There was no difference in the duration of adverse effects after the first and second doses of the vaccines $\left(\chi^{2}=1.268, \mathrm{p}=0.53\right)$. 


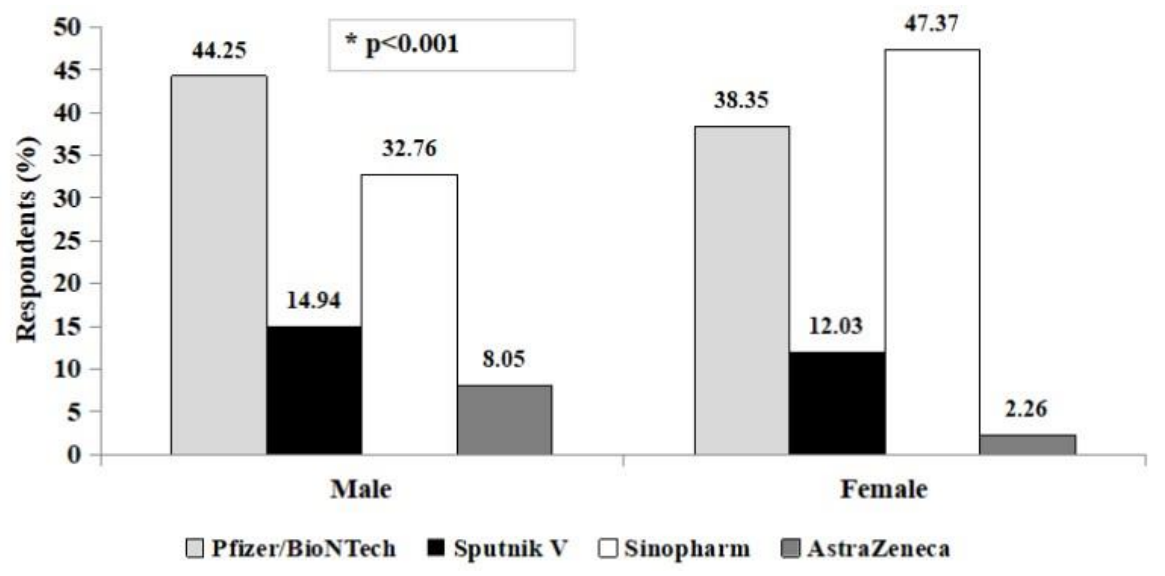

Graph 6. Prevalence of different types of vaccines in relation to gender

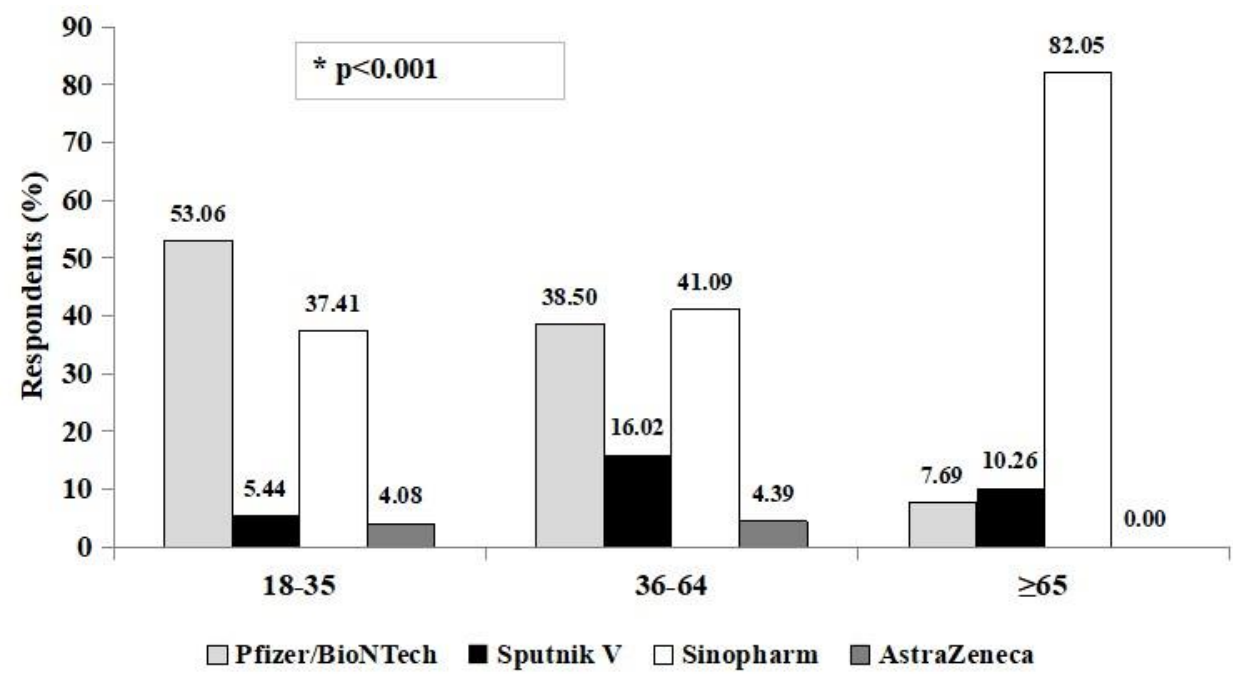

Graph 7. Prevalence of different types of vaccines in relation to age

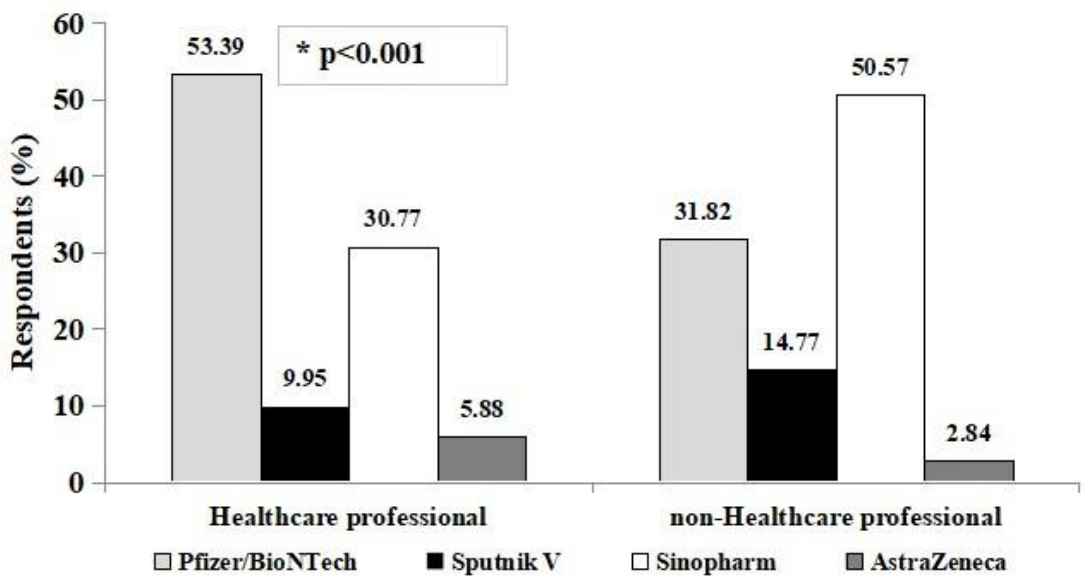

Graph 8. Prevalence of different types of vaccines in relation to professional orientation 


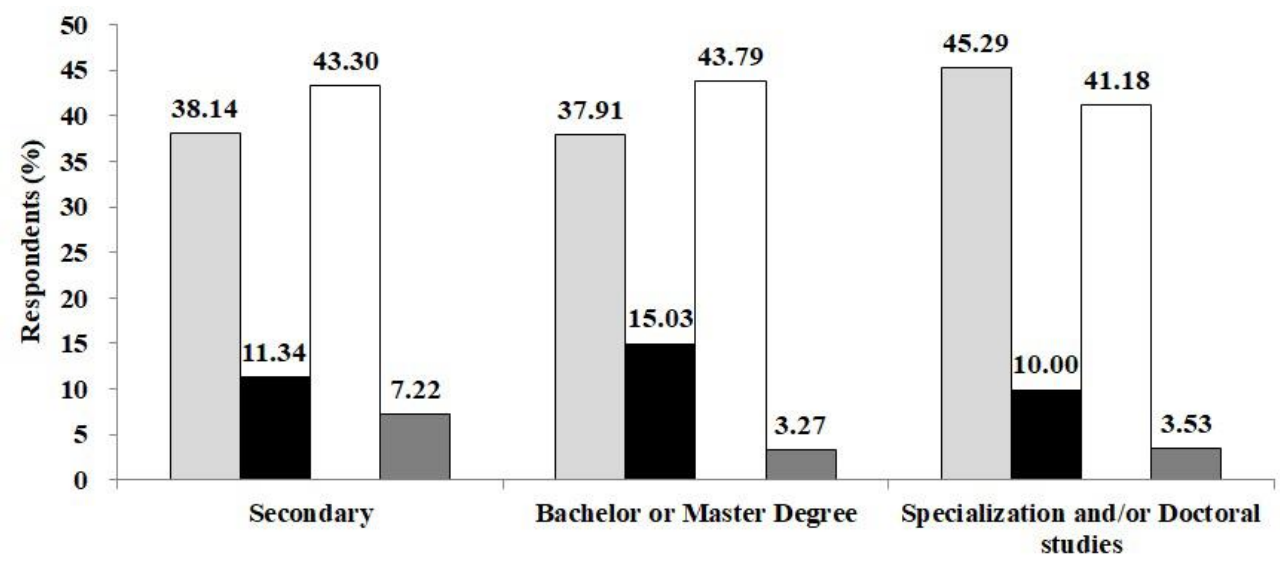

$\square$ Pfizer/BioNTech $\quad$ Sputnik V $\quad \square$ Sinopharm $\square$ AstraZeneca

Graph 9. The prevalence of different types of vaccines in relation to the level of education

Table 2. Adverse effects of vaccines

\begin{tabular}{|c|c|c|}
\hline Adverse effects & $\begin{array}{l}\text { After } 1^{\text {st }} \text { dose of vaccine } \\
\text { Number (percent) }\end{array}$ & $\begin{array}{c}\text { After } 2^{\text {nd }} \text { dose of vaccine } \\
\text { Number (percent) }\end{array}$ \\
\hline "Without & $205(35.78 \%)$ & $188(32.81 \%)$ \\
\hline Local effects & $142(24.78 \%)$ & $95(16.58 \%)$ \\
\hline $\begin{array}{c}\text { Muscle and/or joint pain, } \\
\text { tiredness }\end{array}$ & $68(11.87 \%)$ & $70(12.22 \%)$ \\
\hline $\begin{array}{l}\text { Headache }+ \text { muscle and/or } \\
\text { joint pain, tiredness }\end{array}$ & $\begin{array}{c}61 \text { (18 only headache) } \\
(10.65 \%)\end{array}$ & $\begin{array}{l}54 \text { (16 only headache) } \\
(9.42 \%)\end{array}$ \\
\hline $\begin{array}{c}\text { Fever+muscle and/or joint } \\
\text { pain, tiredness }\end{array}$ & $\begin{array}{c}44(19 \text { only fever) } \\
7.68 \%)\end{array}$ & $\begin{array}{c}96 \text { (60 only fever) } \\
(16.75 \%)\end{array}$ \\
\hline Only systemic side effects & $29(5.06 \%)$ & $51(8.90 \%)$ \\
\hline Local+systemic & $19(3.31 \%)$ & $17(2.97 \%)$ \\
\hline Other & $5(0.87 \%)$ & $2(0.35 \%)$ \\
\hline
\end{tabular}

Local effects: redness and pain at the injection site, pain in the arm where the vaccine was injected Systemic side effects: muscle and/or joint pain, tiredness, fever, headache, confusion and/or dizziness Other: nausea, swollen lymph nodes, tachycardia, thrombosis

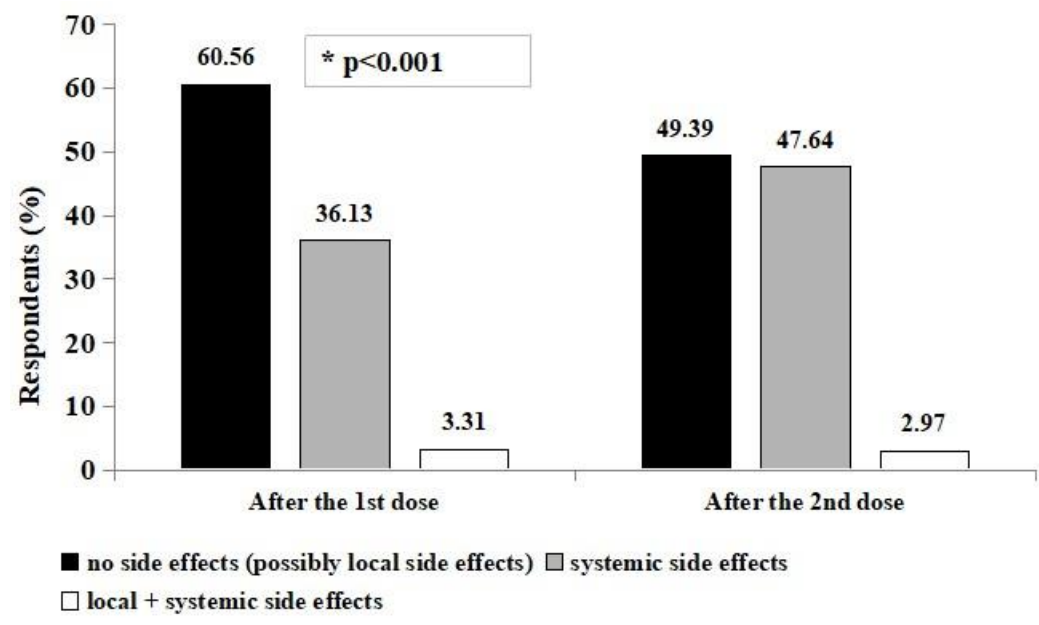

Graph 10. Frequency of adverse effects 


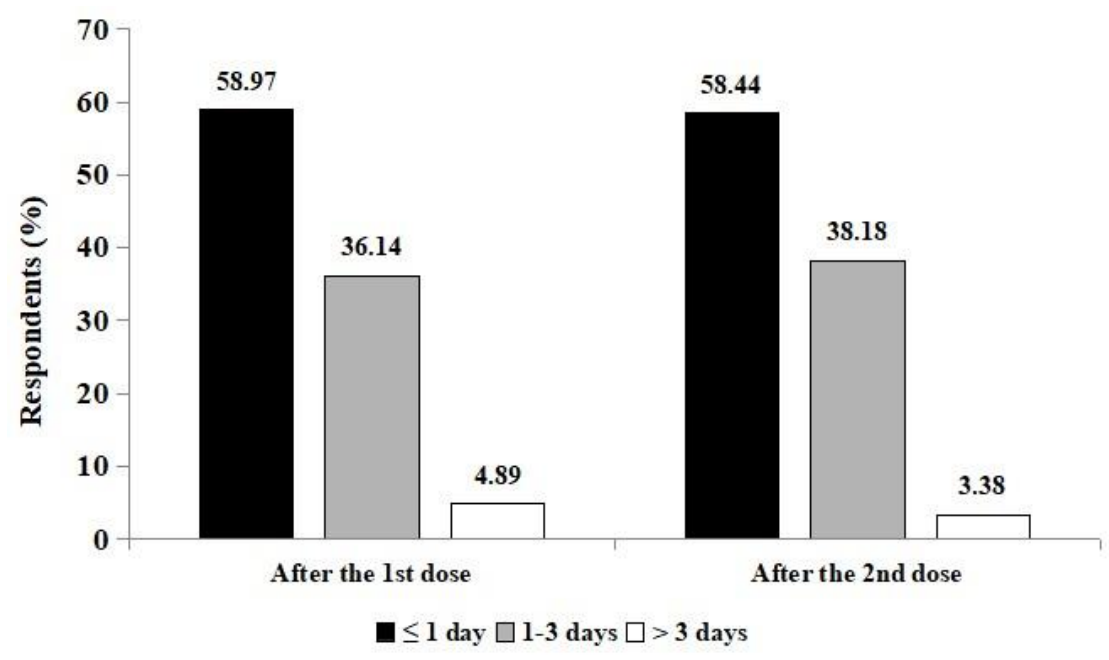

Graph 11. Duration of adverse effects

No severe adverse effects or allergic reactions have been reported in our research. In 5 studies, the incidence of adverse reactions within 28 days after vaccination was less than $30 \%(5,8,15-17)$. The adverse reaction rates of the Pfizer/BioNTech vaccine reported by Walsh (18) and Mulligan (14) were $39.1 \%$ and $52.8 \%$ respectively, while the adverse reaction rate of the adenovirus recombinant vector vaccine reported by Zhu (19) was $73.0 \%$. Allergic reactions to the Pfizer-BioNTech vaccine are described as occurring at a rate of 11.1 cases per million vaccine doses (20). Data showing the important fact that $33 \%$ of patients with confirmed anaphylaxis to the Pfizer-BioNTech mRNA vaccine had a prior history of anaphylaxis (20). Because of that, allergy experts from Mass General Brigham and Vanderbilt University Medical Center developed a guide to risk stratification and safe COVID-19 vaccination, based on a clinical assessment (21). In this way, rapid identification of high-risk individuals needing allergist assessment is enabled, while individuals with lower risk allergy histories are suggested to receive the COVID-19 vaccine per usual protocol with either 15-minute or 30-minute observation periods. In our country, all patients are obliged to stay in the room for at least 15 minutes for observation.

\section{Conclusion}

COVID-19 is an unpredictable and potentially deadly disease. The vaccination process in Serbia started quickly and is still intensive. The current information about the effectiveness and safety of COVID-19 vaccines is encouraging. Mild to moderate adverse effects are expected and usually resolve within one day after vaccination. A widespread vaccination process can lead to pandemic control and a reduction in COVID-19-induced death.

\section{Acknowledgements}

This study was supported by the Faculty of Medicine, University in Niš, Internal scientific project number 15 . 


\section{References}

1. Wang C, Horby PW, Hayden FG, Gao GF. A novel coronavirus outbreak of global health concern. Lancet 2020;395(10223):470-3. [CrossRef] [PubMed]

2. Weiss $P$, Murdoch DR. Clinical course and mortality risk of severe COVID-19. Lancet 2020; 395(10229): 1014-5. [CrossRef] [PubMed]

3. Ritchie $H$, Ortiz-Ospina $E$, Beltekian D, Mathieu $E$, Hasell J, Macdonald B, et al. Serbia: Coronavirus pandemic country profile. "Cited 2021 April 12"; Available from: URL:

https://ourworldindata.org/coronavirus/country/serbia

4. Hajissa K, Mussa A. Positive aspects of the mRNA platform for SARS-CoV-2 vaccines. Hum Vaccin Immunother 2021;8:1-3. [CrossRef] [PubMed]

5. Polack FP, Thomas SJ, Kitchin N, Absalon J, Gurtman $A$, Lockhart $S$, et al. Safety and efficacy of the BNT162b2 mRNA COVID-19 vaccine. N Engl J Med 2020;383(27):2603-15. [CrossRef] [PubMed]

6. Knoll MD, Wonodi C. Oxford-AstraZeneca COVID-19 vaccine efficacy. Lancet 2021;397(10269):72-4. [CrossRef] [PubMed]

7. Baraniuk C. Covid-19: What do we know about Sputnik V and other Russian vaccines? BMJ 2021; 372:743. [CrossRef] [PubMed]

8. Zhang Y, Zeng G, Pan H, Li C, Hu Y, Chu K, et al. Safety, tolerability, and immunogenicity of an inactivated SARS-CoV-2 vaccine in healthy adults aged 18-59 years: a randomised, double-blind, placebocontrolled, phase $1 / 2$ clinical trial. Lancet Infect Dis 2021;21(2):181-92. [CrossRef]

9. Soiza RL, Scicluna C, Thomson EC. Efficacy and safety of COVID-19 vaccines in older people. Age Ageing 2021;50(2):279-83. [CrossRef] [PubMed]

10. Sallam M, Dababseh D, Eid H, Al-Mahzoum K, AlHaidar A, Taim D, et al. High rates of covid-19 vaccine hesitancy and its association with conspiracy beliefs: A study in Jordan and Kuwait among other Arab countries. Vaccines 2021;9(1):42-58. [CrossRef] [PubMed]

11. Earnshaw VA, Eaton LA, Kalichman SC, Brousseau NM, Hill EC, Fox AB. COVID-19 conspiracy beliefs, health behaviors, and policy support. Translational Behavioral Medicine 2020;10(4):850-6. [CrossRef] [PubMed]

12. Wilson $S L$, Wiysonge $C$. Social media and vaccine hesitancy. BMJ Glob Health 2020;5(19):e004206. [CrossRef] [PubMed]
13. Voysey M, Clemens SAC, Madhi SA, Weckx LY, Folegatti PM, Aley PK, et al. Safety and efficacy of the ChAdOx1 nCoV-19 vaccine (AZD1222) against SARSCoV-2: an interim analysis of four randomised controlled trials in Brazil, South Africa, and the UK. Lancet 2021;397(10269):99-111. [CrossRef] [PubMed]

14. Mulligan MJ, Lyke KE, Kitchin N, Absalon J, Gurtman A, Lockhart S, et al. Phase I/II study of COVID-19 RNA vaccine BNT162b1 in adults. Nature 2020; 586 (7830):589-93. [CrossRef] [PubMed]

15. Xia S, Duan K, Zhang Y, Zhao D, Zhang $H$, Xie $Z$, et al. Effect of an inactivated vaccine against SARS-CoV2 on safety and immunogenicity outcomes: Interim analysis of 2 randomized clinical trials. JAMA 2020; 324(10):951-60. [CrossRef] [PubMed]

16. Xia S, Zhang Y, Wang Y, Wang H, Yang Y, Gao GF, et al. Safety and immunogenicity of an inactivated SARSCoV-2 vaccine, BBIBP-CorV: a randomised, doubleblind, placebo-controlled, phase 1/2 trial. Lancet Infect Dis 2021;21(1):39-51. [CrossRef] [PubMed]

17. Pu J, Yu Q, Yin Z, Zhang Y, Li X, Li D, et al. An indepth investigation of the safety and immunogenicity of an inactivated SARS-CoV-2 vaccine. MedRxiv 2020; [CrossRef]

18. Walsh EE, Frenck RW Jr, Falsey AR, Kitchin N, Absalon J, Gurtman A, et al. Safety and immunogenicity of two RNA-based COVID-19 vaccine candidates. N Engl ] Med 2020;383(25):2439-50. [CrossRef] [PubMed]

19. Zhu FC, Guan XH, Li YH, Huang JY, Jiang T, Hou LH, et al. Immunogenicity and safety of a recombinant adenovirus type-5-vectored COVID-19 vaccine in healthy adults aged 18 years or older: a randomised, double-blind, placebo-controlled, phase 2 trial. Lancet 2020;396(10249):479-88. [CrossRef] [PubMed]

20. Centers for Disease Control and Prevention COVID-19 Response Team. Allergic reactions including anaphylaxis after receipt of the first dose of Pfizer-BioNTech COVID-19 vaccine. MMWR 2021;70(2):46-51. [CrossRef] [PubMed]

21. Banerji A, Wickner PG, Saff R, Stone CA, Robinson LB, Long $A A$, et al. mRNA vaccines to prevent COVID-19 disease and reported allergic reactions: current evidence and suggested approach. J Allergy Clin Immunol Pract 2021;9:1423-37. [CrossRef] [PubMed] 


\title{
Originalni rad
}

UDC: 615.371:[616.98:578.834(497.11)

doi: 10.5633/amm.2021.0303

\section{TRENUTNI PRESEK PROCESA VAKCINACIJE PROTIV KORONA VIRUSA U SRBIJI}

\author{
Aleksandra Catić Đorđević ${ }^{1}$, Nikola Stefanović ${ }^{1}$, Ana Spasić ${ }^{1}$, Ivana Damnjanović ${ }^{1}$, \\ Radmila Veličković Radovanović ${ }^{1,2}$, Boris Đinđić1, ${ }^{1}$, Dragana Pavlović ${ }^{1}$
}

\begin{abstract}
${ }^{1}$ Univerzitet u Nišu, Medicinski fakultet, Niš, Srbija
Kontakt: Aleksandra Catić Đorđević

Bulevar dr Zorana Đinđića 81, 18000 Niš, Srbija

E-mail: aleksandra.catic@medfak.ni.ac.rs
\end{abstract}

${ }^{2}$ Univerzitetski klinički centar Niš, Klinika za nefrologiju, Niš, Srbija

${ }^{3}$ Univerzitetski klinički centar Niš, Klinika za kardiovaskularne bolesti, Niš, Srbija

Prošlo je više od godinu dana od početka pandemije izazvane korona virusom COVID19. Timovi istraživača sarađuju na razvoju i unapređivanju vakcina protiv SARS-CoV-2 oboljenja. Četiri COVID-19 vakcine različitih tipova i proizvođača dostupne su u Srbiji od decembra 2020. godine, a građani mogu da se odluče za jednu od njih. Cilj ovog istraživanja bio je da se napravi presek trenutne situacije procesa vakcinacije građana Srbije, u pogledu istraživanja stavova $\mathrm{i}$ neželjenih efekata nakon primljene dve doze vakcine protiv virusa COVID-19, koji izaziva oboljenje SARS-CoV-2. Nakon primene vakcine, očekivani su blagi do umereni neželjeni efekti, lokalni i sistemski.

Prikupljanje podataka izvršeno je putem online ankete, pozivanjem građana da dobrovoljno pristupe popunjavanju upitnika u definisanom periodu, od početka marta do 12 . aprila 2021. godine.

Istraživanje je obuhvatilo 573 ispitanika prosečne starosti 43,55 godina $\pm 13,17$ godina: 174 (30,37\%) muškarca i $399(69,63 \%)$ žena. Najveći broj ispitanika vakcinisan je Pfizer/BioNTech $(40,14 \%)$ ili Sinopharm $(42,93 \%)$ vakcinom, što je u skladu sa dostupnošću vakcina u Srbiji, tokom perioda ispitivanja. Zastupljenost vakcine Pfizer/BioNTech bila je veća među ispitanicima muškog pola, zdravstvenim radnicima i populacijom mlađom od 30 godina. Najčešći prijavljeni lokalni neželjeni efekati bili su bol i osetljivost na mestu uboda. Od sistemskih neželjenih efekata najučestaliji bili su povišena temperatura, bol u mišićima/ zglobovima i umor. Intenzitet neželjenih efekata bio je veći nakon druge doze, a njihovo trajanje kod većine ispitanika iznosilo je jedan dan.

Proces vakcinacije u Srbiji intenzivno traje. Masovna vakcinacija jeste put ka kontroli pandemije, kolektivnom imunitetu i smanjenju smrtnosti izazvane virusom COVID-19 i oboljenjem SARS-CoV-2.

Acta Medica Medianae 2021;60(3):20-29.

Ključne reči: pandemija, COVID-19, SARS-CoV-2, vakcinacija 